\title{
COMPARING EFFECTIVENESS OF MONETARY AND FISCAL POLICIES ON REAL AND NOMINAL SIDES OF THE ECONOMY: A MACRO PANEL ANALYSIS OF SELECTED DEVELOPING COUNTRIES
}

\author{
Meer Jan \\ Lecturer \& PhD scholar \\ Department of Economics \\ Lasbela University of Agriculture, Water and Marine Sciences \\ Uthal, Balochista - Pakistan \\ meeroshah1@gmail.com \\ Arshad Ahmed \\ Lecturer \\ Department of Economics \\ Lasbela University of Agriculture, Water and Marine Sciences \\ Uthal, Balochistan - Pakistan \\ irshadmehr002@gmail.com \\ Munir Ahmed \\ Lecturer \\ Department of Political Studies \\ Lasbela University of Agriculture, Water and Marine Sciences \\ Uthal, Balochistan - Pakistan \\ muniranwar45@gmail.com
}

\section{Abstract}

This paper checks the relative effectiveness of monetary and fiscal policies on real and nominal sides of economy in 11 selected developing countries. The paper employed panel (ARDL) method of pooled mean group estimators using the annual data from 1961 to 2020. To check the robustness of PMG results, the study employed panel DOLS and panel FMOLS. The findings of this study indicated that fiscal policy has a stronger effect than monetary policy in case of developing county on real sector. While, the influence of monetary policy is stronger in changing the nominal side of economy such as price level. In addition to this, the findings also revealed that fiscal policy has no impact on nominal side such as price level. Interestingly, the obtained results are according to 


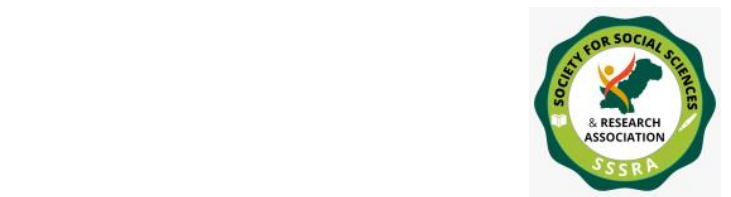

Pak. Journal of Int'L Affairs, Vol 4, Issue 4 (2021)

Comparing effectiveness of monetary and ...

economic theory. Finally, the results are consistent and have very important policy implication.

Key words: Monetary policy, Fiscal Policy, Macro Panel, PMG

\section{Introduction}

Ensuring a sustainable growth and maintaining stable price level has been recognized as important economic policies for economies and welfare of the people. Fiscal and monetary policies are two important tools used to correct the economic issues such as, high inflation, low economic growth, high unemployment, budget deficit and balance of payment deficit (Akram et al., 2011). These economic issues are more severe and serious in case of developing countries as compare to advanced countries. Both policies can be used to help in correcting the disequilibrium in these economic variable.

Effectiveness of both policies on output and inflation is still uncertain. Different school of thoughts argued different explanation regarding the both policies for different economies. Like, Keynesian school of thought favored fiscal policy to stimulate the output. While, monetary policy is less effective as compare to fiscal policy in affecting the real output (Mehmood \& Sial, 2018). Money is treated to be neutral and ineffective in changing the real output but in Keynesian economics money is not neutral and it's effective Mankiw, N. G. (2003).

Effectiveness of both policies also rely upon the economies and their employment levels. For example, advanced countries are near full employment where aggregate demand is high, both monetary and fiscal policies will affect prices more than real output through the channel of aggregate demand (Mankiw, 2003). In developing countries the state is changed, because most of the developing countries are operating below full employment which means further increase in output is possible. Monetary and fiscal policy both increase aggregate demand but aggregate supply will also increase with aggregate demand so their impact on price level will be less. But both of policies affect real output more than price level (Mishkin, 2004).

Previous studies have neglected the effect of both policies on the real and nominal sides of the economy separately. The existing literature also ignore the relative effectiveness of the policies in panel study. This study aims comparing effectiveness of both policies in nominal and real sides of the economy in developing countries. To achieve this goal, this study used appropriate dynamic macro panel model with robustness and diagnostic checks to inspect the relative effectiveness of both policies on real and nominal sides of the economy. 


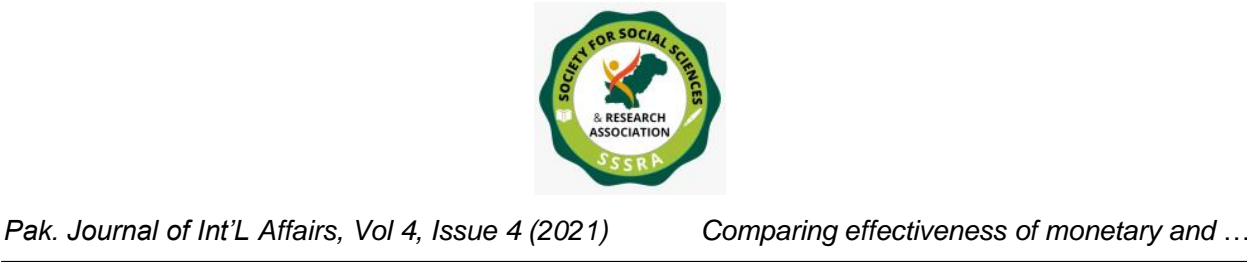

\section{Monetary Policy Stance vs Fiscal policy Stance}

Both policies are used to stabilize the variabilities in the economy, particularly fluctuations in economic growth, inflation and employment. In most of the time, the aim of monetary policy is to stabilize inflation. Monetary policy has direct impact on interest rate and exchange rate and both have very important role in aggregate demand and output. Fiscal policy deal with taxation and expenditure of the government. Government collect the taxes and responsible of provision of public goods. The aim of the fiscal policy is to stabilize economic growth in economy.

The argument over the connection between both policies focuses on the inflationary concerns of government's deficit financing. To avoid inflationary pressure, the central policy recommendation has been given to control of inflation to monetary authority. Fiscal policy i.e. government spending or tax are also used to stabilize price pressure (Bennett and Loayza, 2002).

Now whether monetary policy or fiscal policy better stabilize the inflation or which of them can affect the real output more? To answer this question, this paper is an attempt to investigate relative effectiveness of both policies on real (output) and nominal (inflation) sides of the economy in case of developing countries.

\section{Research Gap}

The existing literature is quite good in finding the effect of monetary or fiscal policy on economic growth but to my knowledge literature have ignored their relative effectiveness on real and nominal variables. Secondly, as pointed by Keynes, both policies have different impact in developing countries. So, this paper will fill the gap by comparing effectiveness of both policies on real (output) and nominal (inflation) sides of the economy in selected developing countries.

\section{Significance of the Study}

Rising prices, low economic growth and high unemployment rate is adversely affecting the economies and standard of living in developing countries. Stable price level and sustainable economic growth are subject to better policies. Both policies are critical for price stability and long-term economic growth.

\section{Research Hypotheses}




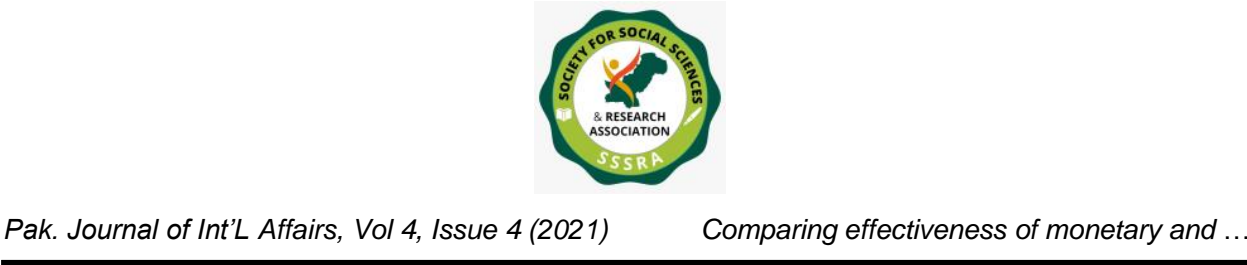

$\mathrm{H}_{0}$ : There is insignificance impact of monetary and fiscal policies on real and nominal sides of the economy in developing countries.

$\mathrm{H}_{1}$ : There is significance impact of monetary and fiscal policies on real and nominal sides of the economy in developing countries.

\section{Literature Review}

\subsection{Theoretical Literature}

The debate on both policies and their impact on real and nominal sides is very old. Some of the economists like classical consider money to be neutral in changing the real side while, the other argued that money is non neutral like John Maynard Keynes. Some of the theoretical works support and give theoretical and practical ground of Keynesian view of active fiscal policy who includes (Schmidt \& Waud, 1973) and (Blinder and Solow, 1974). Moreover, as noticed by (Gramlich, 1971) that the failure of active fiscal policy create new ground for monetarists to attack the believer of active fiscal policy promoters. The monetarists argued that fiscal policy has a very little impact on changing aggregate demand while monetary policy has a higher effect.

Moreover, the view of monetarist (Friedman \& Schwartz, 1965) that monetary policy has higher effect in changing real sector is still very important and applicable as noticed by (Walsh, 1998). Additionally, monetarist were also criticized by some economists like (Benjamin \& Kutner, 1992), and (Tobin, 1970). They re-studied the U.S economy through 1980 s and argued that the influence of monetary policy on income is very little. Finally, there are some other theoretical contribution that favored the theory of Friedman, the works include Gramlich (1971) and Anderson \& Jordan (1968).

\subsection{Empirical Literature}

Bildirici \& Kayikçi, (2013) explained the effectiveness of both policies in case on Nigeria. They took the data from 1981 to 2012 and used pplied ARDL method. The study revealed that monetary policy has a stronger influence in changing the income as compare to fiscal policy in short run. While, in the long run the influence of fiscal policy is stronger than monetary policy. In addition to this, they summed up both the results where fiscal policy is found to be more effective in Nigeria. Coefficients showed that on average monetary and fiscal policy increase the income by $0.40 \%$ and $0.65 \%$ respectively in Nigeria.

(Richard et al., 2017) established the impact of fiscal and monetary policy in case of Rwanda. They have taken quarterly data from 1996 to 2014 and applied recursive VAR. 


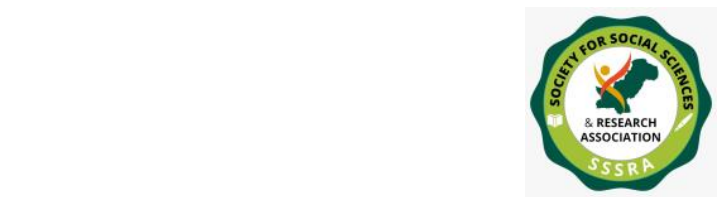

Comparing effectiveness of monetary and ...

Results obtained from variance decomposition and impulse responses indicated that effect of monetary policy is more than effect of fiscal policy in changing the output level only in the short run. Moreover, the study suggest that the government should focus on monetary policy rather than fiscal policy. The study ignored the nominal side and did not use appropriate econometric technique to capture the long run coefficient. One of the disadvantages of using impulse responses is that they are linked with wide confident interval.

Additionally, (Younus, 2009) Using cointegarion and vector error correction mechanism empirically examined and the output response of monetary and fiscal policy in Bangladesh. The result of the study showed that fiscal policy is less important in changing output than monetary policy in alerting the real GDP. The paper recommend that monetary policy has to be used rather than fiscal policy. Similarly, (Abu Hasan, 2016) found that the income effect monetary policy is higher than fiscal policy in short and long run in Bangladesh. Moreover, Latif \& Chowdhury, (1998) used OLS revealed that fiscal policy is effect the economy more than monetary in short run in Bangladesh.

(Beyene, 2021) examined the comparative effect of monetary and fiscal policies on industrial growth of Ethiopia from time period of 1974 to 2018. The study applied VECM method. Both the policies found to be effective in growth of industrial sector in Ethiopia. Moreover, monetary policy affects the industrial growth more than fiscal policy. The coefficient of monetary policy found to be 0.51 and the coefficient of fiscal policy is found to be 0.26. Furthermore, the paper also argued that money is not neutral in case of Ethiopia and the empirical results are according to monetarist theory of effectiveness of money in economy.

Moreover, (Özer \& Karagöl, 2018) analyze the growth effect of monetary and fiscal policy in Turkey for the period of 1998 to 2016. The study used some important time series technique such as ARDL and granger test of causality. The outcomes of this study shown that monetary policy is only effectiveness in short run but not in the long run. Moreover, fiscal policy is effective in the long run.

Finally, (Kaur \& Kaur, 2008) explored the relationship between both on real output in case of Indian economy. The study took the data of 25 year from 1980 to 2005 and divided the time period into two sub parts namely 1980-1991(pre-reform era) and 1991-2005 (prereform era). The empirical findings using granger causality revealed that fiscal policy is more influencial in pre-reform era while, monetary policy effect the economy more in post-reform era in Indian economy. In addition to this, the study also recommended that both the policies are complement to each other but not substitutes. 


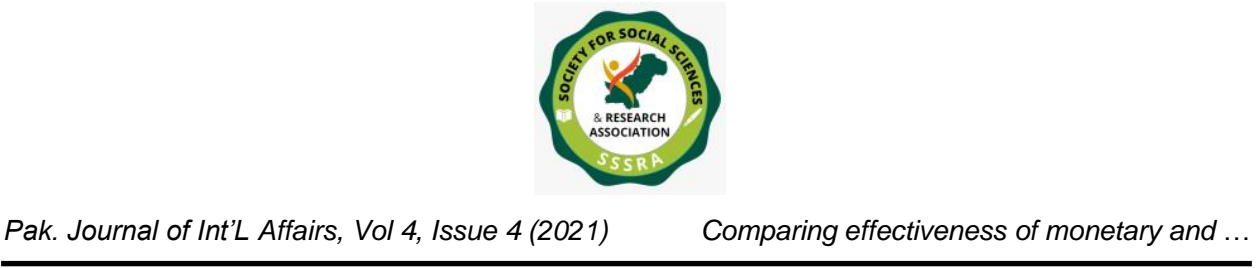

\section{Data and Method}

\subsection{Data}

The data are obtained from world development indicator, World Bank for the time period of 1961 to 2020. Inflation and GDP are the dependent variables, money supply and government expenditure are main independent variables while, gross capital formation (proxy for investment) and exports are used as control variables. The data of 11 selected developing countries are taken namely; India, Iran, Bolivia, Pakistan, Sri Lanka, Honduras, Rwanda, Peru, Philippines, Chile and Malaysia.

\subsection{Econometric Techniques}

Several econometric approaches were used in this research. The panel unit root test is used to determine whether the variables are stationary. Second, Pedroni and Kao tests are employed to confirm the variables' long-term relationship. Finally, short and long run coefficients are calculated using the panel mean group estimator. Fourthly, for robustness check panel FMOL and panel DOLS methods are used and finally, multicollinearity, cross section dependence test and descriptive statistics are also carried out.

\subsubsection{Cross section Dependence Test}

This is one of the main diagnostic test that has to be performed before estimating a panel model. This study used 4 different cross section dependence test namely, (Breusch \& Pagan, 1980) LM test, (Pesaran \& Shin, 2004) test, (Pesaran , 2004) test and (Baltagi et al., 2012) test. Pesaran scaled test is more appropriate that other proposed test in case of macro panel where time is greater than cross sections (Egn \& Tugcu, 2018).

\subsubsection{Panel Unit Root Test}

Before applying any long run model it is essential to form the stationarity of the variables. On the basis of stationary order of the variables the appropriate model can be chosen. For stationary test, the study used Pesaran \& shin (IPS) and Levin Lin \& Chu (LLC) tests. One of the advantage of IPS is that it allows heterogeneity in intercept and slope (Bildirici \& Kayikçi, 2013). Moreover, LLC allows for time effect, individual effect and time trend (Bornhorst et al., 2006).

\subsubsection{Cointegration Test}




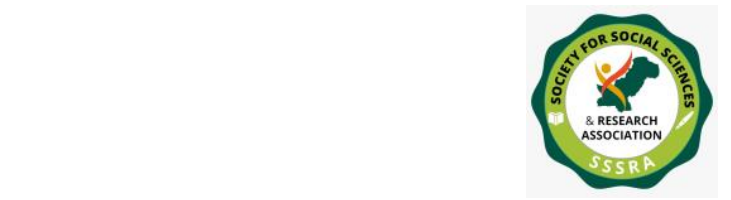

Comparing effectiveness of monetary and ...

After conducting unit root, the next step is to determine whether or not long run associations exist. Pedroni and Kao cointegration tests were employed in this investigation. The pedroni tests allow for significant heterogeneity among individual members (Pedroni, 1999). Second method used in this study is recommended by (Kao, 1999) which is more suitable in case of panel in the assumption of heterogeneous cross sectional units.(Egn \& Tugcu, 2018).

\subsubsection{Panel ARDL}

Pesaran et al., (2005) proposed this approach (1999). This method has some advantages over other dynamic models presented by Arellano (1989), such as fixed effects and GMM estimators; Arellano and Bover (1995). When number of years are greater than number of countries or $\mathrm{T}>\mathrm{N}$ then the variables might not be stationary at level. The other dynamic methods produce inconsistence results of average of the parameters (da Silva et al., 2018). Since, this study includes the sample of 11 countries and 59 years, the variables are nonstationary and cointegrated. That's why panel ARDL is appropriate technique. Another advantage of panel ARDL is that it produces both short and long run coefficients.

\subsection{Empirical Model}

The following model specifications are used to check the influence of monetary and fiscal policies on real and nominal sides:

$G D P=f(M S, G S, E X P R T, G C F)$

$I N F L A T I O N=f(M S, G S, E X P R T, G C F)$

Where, GDP and Inflation are used as proxy to measure real side and nominal sides of economy, MS is money supply, GS is government final spending proxy for fiscal policy, GCF (proxy for investment) and Export are used as control variables.

Moreover, this relationship can be expressed in linear model as follow:

$G D P_{i t}=\beta_{0}+\beta_{1 t} M S_{i t}+\beta_{2 t} G S_{i t}+\beta_{3 t} E X P R T_{i t}+\beta_{4 t} G C F_{i t}$

$I N F_{i t}=\beta_{0}+\beta_{1 t} M S_{i t}+\beta_{2 t} G S_{i t}+\beta_{3 t} E X P R T_{i t}+\beta_{4 t} G C F_{i t}$

Finally the panel ARDL model including short run and long run coefficient can be written as follow: 


$$
\begin{aligned}
\Delta G D P_{i t}=\beta_{0}+ & \sum_{k=1}^{p} \beta_{1, i k} \Delta G D P_{i, t-k}+\sum_{k=0}^{q 1} \beta_{2, i k} \Delta M S_{i, t-k}+\sum_{k=0}^{q 2} \beta_{3, i k} \Delta G S_{i, t-k} \\
& +\sum_{k=0}^{q 3} \beta_{4, i k} \Delta E X P R T_{i, t-k}+\sum_{k=0}^{q 4} \beta_{5, i k} \Delta G C F_{i, t-k}+\gamma_{1} G D P_{i, t-k}+\gamma_{2} M S_{i, t-k} \\
& +\gamma_{3} G S_{i, t-k}+\gamma_{4} E X P R T_{i, t-k}+\gamma_{5} G C F_{i, t-k}+\varepsilon_{i t} \\
\Delta I N F_{i t}=\beta_{0}+ & \sum_{k=1}^{p} \beta_{1, i k} \Delta I N F_{i, t-k}+\sum_{k=0}^{q 1} \beta_{2, i k} \Delta M S_{i, t-k}+\sum_{k=0}^{q 3} \beta_{3, i k} \Delta G S_{i, t-k} \\
& +\sum_{k=0}^{q 3} \beta_{4, i k} \Delta E X P R T_{i, t-k}+\sum_{k=0}^{q} \beta_{5, i k} \Delta G C F_{i, t-k}+\gamma_{1} I N F_{i, t-k}+\gamma_{2} M S_{i, t-k} \\
& +\gamma_{3} G S_{i, t-k}+\gamma_{4} E X P R T_{i, t-k}+\gamma_{5} G C F_{i, t-k}+\varepsilon_{i t}
\end{aligned}
$$

Where, $\Delta$ is differenced operator, $\mathrm{i}=1,2,3,4,5 \ldots \mathrm{N}, \mathrm{t}=1,2,3,4,5 \ldots . \mathrm{T}$. $\beta_{0}$ is fixed effects, $\beta_{1}$ to $\beta_{5}$ are short run coefficient, $\gamma_{1}$ to $\gamma_{5}$ are long run coefficients and $\varepsilon_{i t}$ is the white noise error term. In addition to this, once short and long run relationship is establish from equation (6) panel error correction mechanism can be written as follow:

$$
\begin{aligned}
\Delta G D P_{i t}=\beta_{0}+ & \sum_{k=1}^{p} \beta_{1, i k} \Delta G D P_{i, t-k}+\sum_{k=0}^{q 1} \beta_{2, i k} \Delta M S_{i, t-k}+\sum_{k=0}^{q 2} \beta_{3, i k} \Delta G S_{i, t-k} \\
& +\sum_{k=0}^{q 3} \beta_{4, i k} \Delta E X P R T_{i, t-k}+\sum_{k=0}^{q 4} \beta_{5, i k} \Delta G C F_{i, t-k}+\theta E C M_{i, t-1}+\varepsilon_{i t} \\
\Delta I N F_{i t}=\beta_{0}+ & \sum_{k=1}^{p} \beta_{1, i k} \Delta I N F_{i, t-k}+\sum_{k=0}^{q 1} \beta_{2, i k} \Delta M S_{i, t-k}+\sum_{k=0}^{q 4} \beta_{3, i k} \Delta G S_{i, t-k} \\
& +\sum_{k=0}^{q 4} \beta_{4, i k} \Delta E X P R T_{i, t-k}+\sum_{k=0} \beta_{5, i k} \Delta G C F_{i, t-k}+\theta E C M_{i, t-1}+\varepsilon_{i t}
\end{aligned}
$$

Where, $\theta$ is slope of ECM, it measures the adjustment speed.

\section{Results and Discussions}


Results of descriptive analysis are shown in table 1. Since mean and median of export, GCF, GDP and GS are close indicating that the data of these variables have no extreme value. Secondly, mean and median of INF and MS are not close mean is higher than median in both cases, it means there is extreme positive values. The observations of other variables are 647 (because $\mathrm{T}=59$ and $\mathrm{N}=11$ ) expect $\mathrm{MS}$, the reason is that there are some missing data in MS.

Table 1: Descriptive statistics results

\begin{tabular}{|l|l|l|l|l|l|l|}
\hline & MS & INF & GS & GDP & GCF & EXPORT \\
\hline Mean & 48.86890 & 51.1321 & 5.2038 & 4.3866 & 6.5023 & 5.8845 \\
\hline Median & 16.84582 & 7.3733 & 4.56977 & 4.9597 & 5.9715 & 5.3045 \\
\hline Maximum & 6987.877 & 12338.6 & 70.6418 & 35.224 & 155.78 & 93.333 \\
\hline & & & & & & \\
Minimum & 43.73826 & -8.7173 & -60.8559 & -50.248 & -81.772 & -66.104 \\
\hline Observations & 641 & 647 & 647 & 647 & 647 & 647 \\
\hline Countries & 11 & 11 & 11 & 11 & 11 & 11 \\
\hline
\end{tabular}

Correlation matrix is used to check whether problem of multicollinearity exist between the independent variables or not? Since the all correlation coefficients between the variables are less than 0.80 and greater than -0.80 which shows that there is no problem of multicollinearity between the independent variables.

Table 2: Correlation Matrix

\begin{tabular}{|l|l|l|l|l|}
\hline & MS & GS & GCF & Export \\
\hline MS & 1.0000 & -0.1110 & 0.0113 & 0.0957 \\
\hline GS & -0.1110 & 1.0000 & 0.1332 & 0.1520 \\
\hline GCF & -0.0113 & 0.1332 & 1.0000 & 0.0745 \\
\hline Export & -0.0957 & 0.1520 & 0.0745 & 1.0000 \\
\hline
\end{tabular}

Before proceeding to panel unit root tests, it is necessary to check for cross section dependence test. Table 3 presents the cross section dependence test result. Four different methods are used as shown in the table. 
Table 3: Cross section dependence test

\begin{tabular}{|l|l|l|l|l|}
\hline Variable & $\begin{array}{l}\text { Breusch } \\
\text { Pagan }\end{array}$ & $\begin{array}{l}\text { Pesaran } \\
\text { scaled }\end{array}$ & $\begin{array}{l}\text { Bias corrected } \\
\text { scaled }\end{array}$ & $\begin{array}{l}\text { Pesaran } \\
\text { CD }\end{array}$ \\
\hline GDP & $138.5145^{* * *}$ & $7.9627 * * *$ & $7.8695 * * *$ & $6.4761 * * *$ \\
\hline MS & $125.5492^{* * *}$ & $6.7266 * * *$ & $6.6333 * * *$ & $4.3681 * * *$ \\
\hline GS & $89.5201 * * *$ & $3.2913 * * *$ & $3.1981 * * *$ & $2.7667 * * *$ \\
\hline Export & $104.56 * * *$ & $4 . .7255^{* * *}$ & $4.6323 * * *$ & $5.0749 * * *$ \\
\hline GCF & $80.3934 * *$ & $2.4211^{* *}$ & $2.3279 * *$ & $1.7456 *$ \\
\hline INF & $168.1526 * * *$ & $10.7886 * * *$ & $10.6954 * * *$ & $8.7230 * * *$ \\
\hline
\end{tabular}

Note: ***,** and $*$ means rejecting $\mathrm{H}_{0}$ at 1,5 and $10 \%$ level.

Null hypothesis of these methods assumes cross section independence while, alternative hypothesis assumes cross sections dependence. Since null hypothesis is rejected using all the methods, it means there is cross section-dependence. Under the cross-section dependency other standard econometric method may produce insufficient results. While, PMG take account of this problem and produce sufficient result in presence of cross section-dependence (Rahman \& Alam, 2021).

Table 4: Panel unit root test

\begin{tabular}{|c|c|c|c|c|}
\hline \multirow[t]{2}{*}{ Variables } & \multicolumn{2}{|c|}{ Levin, Lin \& Chu } & \multicolumn{2}{|c|}{ Pesaran and Shin W-stat } \\
\hline & Intercept & $\begin{array}{l}\text { Intercept } \\
\text { with trend }\end{array}$ & Intercept & $\begin{array}{l}\text { Intercept } \\
\text { with trend }\end{array}$ \\
\hline \multicolumn{5}{|l|}{ At level } \\
\hline GDP & -1.2810 & 0.7287 & $-9.2848 * * *$ & $-8.2420 * * *$ \\
\hline MS & -1.6658 & -1.1502 & -0.2861 & -0.5556 \\
\hline GS & $-9.1101 * * *$ & $-8.7519 * * *$ & $\begin{array}{l} \\
11.5808 * * *\end{array}$ & $-10.2410 * *$ \\
\hline EXPRT & $-8.3880 * * *$ & $13.8455^{* * *}$ & $215.49 * * *$ & $\begin{array}{l}- \\
13.0009 * * *\end{array}$ \\
\hline INF & -0.2080 & -0.0987 & $-4.0216^{* * *}$ & $-2.6364 * * *$ \\
\hline GCF & $-13.4377 * * *$ & $\begin{array}{l}- \\
12.9590 * * *\end{array}$ & $\begin{array}{l}- \\
13.7877 * * *\end{array}$ & $\begin{array}{l}- \\
12.6704 * * *\end{array}$ \\
\hline \multicolumn{5}{|c|}{ At First difference } \\
\hline GDP & $-10.0925 * * *$ & $-7.5037 * * *$ & --------- & --------- \\
\hline INF & $-10.4791 * * *$ & $-8.6865 * * *$ & -------- & --------- \\
\hline
\end{tabular}

Note: $* * *$ and $* *$ means rejecting $\mathrm{H}_{0}$ at 1 and $5 \%$ level. 
Before choosing the best model to estimate the coefficients, first step is to check the stationary order of the variables.

Table 5: Pedroni panel test of cointegration

\begin{tabular}{|c|c|c|c|}
\hline \multicolumn{4}{|c|}{ Model 1} \\
\hline \multicolumn{2}{|c|}{ Within dimension } & \multicolumn{2}{|c|}{ Between dimension } \\
\hline Panel V & -0.0149 & Group rho & $-10.5960 * * *$ \\
\hline Panel rho & $-9.6508 * * *$ & Group PP & $-14.5609 * * *$ \\
\hline Panel PP & $-12.0016 * * *$ & Group ADF & $-8.3201 * * *$ \\
\hline Panel ADF & $-8.7360 * * *$ & & \\
\hline \multicolumn{4}{|c|}{ Model 2} \\
\hline Panel V & -1.0608 & Group rho & $-11.5592 * * *$ \\
\hline Panel rho & $-16.6684 * * *$ & Group PP & $-16.4336 * * *$ \\
\hline Panel PP & $-20.3433 * * *$ & \multirow[t]{2}{*}{ Group ADF } & $-6.9769 * * *$ \\
\hline Panel ADF & $-6.1525 * * *$ & & \\
\hline \multicolumn{4}{|c|}{ Kao Cointegration test } \\
\hline & \multicolumn{2}{|l|}{ Model 1} & Model 2 \\
\hline T-statistic (ADF) & \multicolumn{2}{|l|}{$-5.3553 * * *$} & $2.0974 * *$ \\
\hline
\end{tabular}

Note: $* * *$ and $* *$ means rejecting null at $1 \& 5 \%$ level.

In presence of cross section dependence there is chance that stationary order of series exceed I (1) (Smolović et al., 2020). Table 5 displays results of unit root test of both the models. The study used 2 different unit root tests i.e. (LLC) and Pesaran and Shin tests. Null hypothesis assumes non stationary while, the alternative assumes stationary. Only GDP and INF are stationary at first difference using LLC test and other remaining variables are stationary at level. 
Table 6: Results of PMG estimation (Dependent variable is GDP for model 1 and Inflation for Model 2)

\begin{tabular}{|l|l|l|}
\hline Long run & Model 1 & Model 2 \\
\hline Variables & -0.0004 & $0.3112^{* * *}$ \\
& $(0.0008)$ & $(0.0601)$ \\
\hline GS & $0.0693 *$ & -0.1180 \\
& $(0.0364)$ & $(0.0766)$ \\
\hline Export & $0.0797 * * *$ & $-0.1244 * *$ \\
& $(0.0260)$ & $(0.0550)$ \\
\hline GCF & $0.0672^{* * *}$ & -0.0062 \\
& $(0.0214)$ & $(0.0529)$ \\
\hline ECT & $-0.7056^{* * *}$ & $-0.5280 * * *$ \\
& $(0.0655)$ & $(0.0997)$ \\
\hline Short run & \multicolumn{2}{|l|}{} \\
\hline$\Delta$ MS & $-0.0416^{*}$ & 0.3081 \\
& $(0.0251)$ & $(0.2508)$ \\
\hline$\Delta$ GS & 0.0605 & -0.9466 \\
& $(0.0369)$ & $(0.6775)$ \\
\hline$\Delta$ Export & -0.0015 & $1.0117 *$ \\
& $(0.0208)$ & $(0.5244)$ \\
\hline$\Delta$ GCF & 0.0253 & 0.0679 \\
& $(0.0204)$ & $(0.0583)$ \\
\hline Constant & $2.2995 * * *$ & 2.8386 \\
& $(0.3538)$ & $(1.8583)$ \\
\hline
\end{tabular}

Note: $* * *, * *$ and $*$ means rejecting $\mathrm{H}_{0}$ at 1,5 and $10 \%$ level. Figures in () are standard errors

Table 6 indicates PMG estimates both models. The empirical results of both the models are clearly supporting the economic theories. In model 1, money supply is statistically insignificance meaning that monetary policy has no impact on GDP growth (real side) in the selected developing countries. Moreover, the coefficient of government spending is indicating that one unit increase in government spending increase the GDP growth by 0.063 units in the long run. Additionally, both control variables have positively related with GDP growth. In second model GS and GCF are statistically insignificance which means they have no impact on inflation (nominal side), export is negatively related with inflation. While, the coefficient of money supply is 0.3112 indicating that increase in

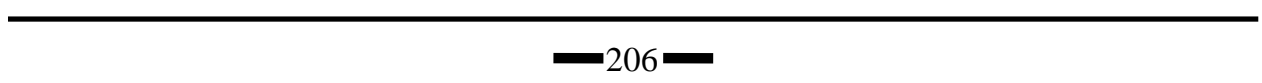




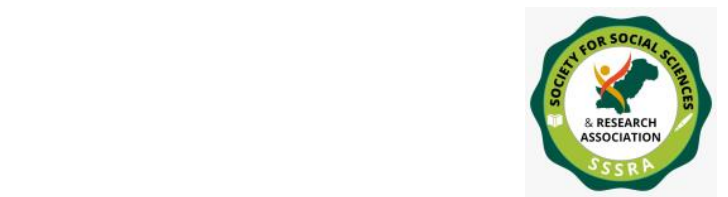

Comparing effectiveness of monetary and ...

money by one unit will increase inflation by 0.3112 units. In short run money supply is negatively related with GDP growth and export is positively related with inflation. All the remaining dependent variables are statistically insignificance in both models. Finally, coefficient of ECT in both models are negative and statistically significance at $1 \%$ level as expected. Any short run disequilibrium will converge back to long run equilibrium at speed of $70.5 \%$ and $52.8 \%$ each period in model 1 and 2 respectively. Empirical findings of this study are in line with the findings of (Okorie et al., 2017);(Younus, 2009);(Fatima \& Iqbal, 2003) and (Chingarande, 2015).

Table 7: Panel FMOLS and Panel DOLS results (GDP and inflation are dependent variable of model $1 \& 2$ respectively)

\begin{tabular}{|l|l|l|l|l|}
\hline & \multicolumn{2}{|c|}{ Model 1 } & \multicolumn{2}{c|}{ Model 2 } \\
\hline Variables\Method & PFMOLS & PDOLS & PFMOLS & PDOLS \\
\hline MS & $-0.008^{*}$ & $-0.0012 *$ & $1.3847 * * *$ & $1.3375^{* * *}$ \\
& $(0.0004)$ & $(0.006)$ & $(0.0161)$ & $(0.0241)$ \\
\hline GS & $0.0570 * * *$ & $0.0990^{* * *}$ & 0.1233 & 0.6118 \\
& $(0.0204)$ & $(0.0388)$ & $(0.6755)$ & $(1.3690)$ \\
\hline Export & $0.0910 * * *$ & $0.2186 * * *$ & 0.1051 & 0.1747 \\
& $(0.0155)$ & $(0.0266)$ & $(0.5139)$ & $(0.9402)$ \\
\hline GCF & $0.1520 * * *$ & $0.1441 * * *$ & -0.0707 & -0.9531 \\
& $(0.0128)$ & $(0.0239)$ & $(0.4251)$ & $(0.8440)$ \\
\hline
\end{tabular}

Note: $* * *, * *$ and $*$ means rejecting $\mathrm{H}_{0}$ at 1,5 and $10 \%$ level. Figure in () are standard errors.

Results of panel FMOLS and panel dynamic OLS are depicted in table 7. The coefficients of both models were obtained using panel FMOLS and panel dynamic OLS to check the robustness of PMG estimation by comparing the coefficients. The obtained results of both the dynamic models are in line with the results of PMG estimation for most of the variables expect MS in model 1 and export in model 2.

\section{Conclusion and Policy Implication}

Both fiscal and monetary policies are important to maintain a sustainable economic growth and stable price level. In most of developing countries economic growth and price level are found to be unstable. Previous studies focus on the comparative influence of both policies on country level and take consideration only the real side of economy such as GDP. The purpose of the work is to compare effectiveness of monetary and fiscal policies on real and nominal sides of the economy in selected developing countries based on data availability and nature of the study. The study take the data of 11 developing countries from the time 
period of 1961 to 2020 and applied PMG estimation. GDP growth is used as proxy to measure real side and inflation is used to measure the nominal side. Money supply and government spending are used as proxies to measure fiscal and monetary policies respectively. In addition to this, gross capital formation (proxy for investment and exports are used as control variables. The findings of the study revealed that fiscal policy is stronger impact in changing the real side of the economy in short and long run both while, monetary policy only affects the nominal side of the economy in the long run in selected developing countries. Moreover to check the robustness, panel dynamic OLS and panel FMOLS are used. Most of the results of both the dynamic models are in line with the results obtained from PMG estimations. Overall, this study concludes that to maintain a stable price level and sustainable growth both fiscal and monetary policies are very important in developing countries. Based on obtained result the study recommend policy maker to focus on fiscal policy to stimulate GDP growth. While, for stable price level policy makers are recommended to use monetary policy. 


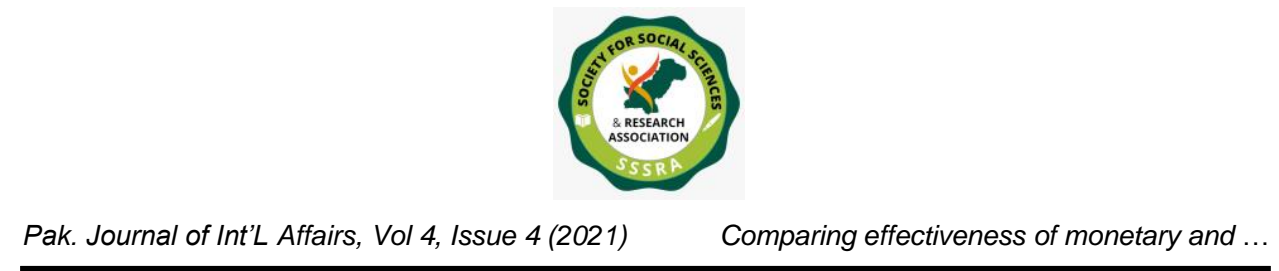

References

Abu Hasan, M. . (2016). The Relative Effectiveness of Monetary and Fiscal Policies on Economic Growth in BangladeshEconomics,

Adefeso, H. A., \& Mobolaji, H. I. (2010). The fiscal-monetary policy and economic growth in Nigeria: Further empirical evidence. Pakistan Journal of Social Sciences, 7(2), 137-142.

Akram, N., Padda, I. U. H., \& Rais, S. I. (2011). Effectiveness of Monetary and Fiscal Policies in Determination of Inflation in Pakistan. Journal of Social and Policy Sciences, 01(02), 57-77.

Baltagi, B. H., Feng, Q., \& Kao, C. (2012). A Lagrange Multiplier test for cross-sectional dependence in a fixed effects panel data model. Journal of Econometrics, 170(1), 164-177.

Bennett, H., \& Loayza, N. (2002). Policy biases when the monetary and fiscal authorities have different objectives. Banco Central de Chile.

Beyene, T. (2021). The Relative Effectiveness of Monetary and Fiscal Policies on Industrial Growth of Ethiopia. May.

Bildirici, M. E., \& Kayikçi, F. (2013). Effects of oil production on economic growth in Eurasian countries: Panel ARDL approach. Energy, 49(1), 156-161.

Blinder, A. S., \& Solow, R. M. (1974). Analytical foundations of fiscal policy.

Bornhorst, F., Baum, C. F., Bornhorst, F., \& Baum, C. (2006). LEVINLIN: Stata module to perform Levin-Lin-Chu panel unit root test. July, 1-3.

Breusch, T. S., \& Pagan, A. R. (1980). The Lagrange Multiplier Test and its Applications to Model Specification in Econometrics. The Review of Economic Studies, 47(1), 239.

Chingarande, A. A. (2015). The Relative Effectiveness of Monetary and Fiscal Policies on Economic Activity in Zimbabwe (1981:4-1998:3) “An Error Correction Approach.” SSRN Electronic Journal, January.

da Silva, P. P., Cerqueira, P. A., \& Ogbe, W. (2018). Determinants of renewable energy growth in Sub-Saharan Africa: Evidence from panel ARDL. Energy, 156, 45-54.8

Egn, E. N., \& Tugcu, C. T. (2018). Panel Data Analysis in the. In The Economics and Econometrics of the Energy-Growth Nexus. Elsevier Inc.

Fatima, A., \& Iqbal, A. (2003). THE RELATIVE EFFECTIVENESS OF MONETARY AND FISCAL POLICIES: An Econometric Study. Pakistan Economic and Social Review, 41(1/2), 93-116.

Friedman, M., \& Schwartz, A. J. (1965). Money and Business Cycles Chapter: Vol. I.

Friedman, B. M., \& Kuttner, K. N. (1992). Money, income, prices, and interest rates. The American Economic Review, 472-492.

Gramlich, E. M. (1971). The usefulness of monetary and fiscal policy as discretionary stabilization tools. Journal of Money, Credit and Banking, 3(2), 506-532.

Kao, C. (1999). Spurious regression and residual-based tests for cointegration in panel data. Journal of Econometrics, 90(1), 1-44. h

Kaur, S., \& Kaur, G. (2008). An Econometric Study of Relative Effectiveness of Monetary and 


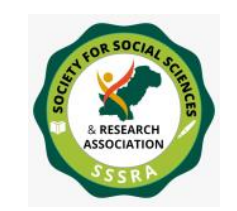

Comparing effectiveness of monetary and ...

Fiscal Policy in India. Paradigm, 12(1), 98-103.

Latif, E., \& Chowdhury, M. H. (1998). Relative effectiveness of monetary and fiscal policy. Bank Parikrama, 23(1\&2), 97.

Mahmood, T., \& Sial, M. H. (2011). The relative effectiveness of monetary and fiscal policies in economic growth: A case study of Pakistan. Asian Economic and Financial Review, 1(4), 236.

Mankiw, N. G. (2003). Macroeconomics (Vol. 41). New York: Worth Publishers.

Mishkin Frederic, S. "The Economics of Money, Banking and Financial Markets." Mishkin Frederic-Addison Wesley Longman (2004).

Okorie, D. I., Sylvester, M. A., \& Simon-Peter, D.-A. C. (2017). Relative Effectiveness of Fiscal and Monetary Policies in Nigeria. Asian Journal of Social Science Studies, 2(1), 117.

Özer, M., \& Karagöl, V. (2018). Relative effectiveness of monetary and fiscal policies on output growth in Turkey: an ARDL bounds test approach. Equilibrium, 13(3), 391-409.

Pedroni, P. (1999). Critical values for cointegration tests in heterogeneous panels with multiple regressors. Oxford Bulletin of Economics and Statistics, 61(SUPPL.), 653-670.

Pesaran, M. H., Pesaran, M. H., Shin, Y., \& Smith, R. P. (1999). Pooled Mean Group Estimation of Dynamic Heterogeneous Panels. Journal of the American Statistical Association, 94(446), 621-634.

Pesaran, M.H., 2004. General diagnostic tests for cross section dependence in panels. Cambridge Working Papers in Economics No: 0435. Faculty of Economics, University of Cambridge.

Rahman, M. M., \& Alam, K. (2021). Exploring the driving factors of economic growth in the world's largest economies. Heliyon, 7(5), 1-9.

Richard, K., Muriu, P. W., \& Maturu, B. (2017). Relative Effectiveness of Monetary and Fiscal Policies on Output Stabilization in Developing Countries: Evidence from Rwanda. International Journal of Economics and Finance, 10(1), 220.

Schmidt, P., \& Waud, R. N. (1973). The almon lag technique and the monetary versus fiscal policy debate. Journal of the American Statistical Association, 68(341), 11-19.

Smolović, J. C., Muhadinović, M., Radonjić, M., \& Đurašković, J. (2020). How does renewable energy consumption affect economic growth in the traditional and new member states of the European Union? Energy Reports, 6(June), 505-513.

Tobin, J. (1970). Money and income: post hoc ergo propter hoc?. The Quarterly Journal of Economics, 301-317.

Walsh, C. (1998). Monetary Theory and Policy the MIT Press. Cambridge MA.

Younus, S. (2009). Relative Effectiveness of Monetary and Fiscal Policies on Output Growth in Bangladesh: A Co integration and Vector Error Correction Approach. 